\title{
Facile Synthesis of Nitriles and Amides from Aldehyde over Heterogeneous Reusable Copper Fluorapatite (CuFAP) Catalyst under Neat Reaction Condition
}

\author{
Santosh S. Chavan, Mohsinkhan Y. Pathan, Taufeekaslam M. Y. Shaikh, Shafeek A. R. Mulla* \\ Chemical Engineering and Process Development Division, National Chemical Laboratory, Pune, India \\ Email: ^sa.mulla@ncl.res.in
}

How to cite this paper: Chavan, S.S., Pathan, M.Y., Shaikh, T.M.Y. and Mulla, S.A.R. (2017) Facile Synthesis of Nitriles and Amides from Aldehyde over Heterogeneous Reusable Copper Fluorapatite (CuFAP) Catalyst under Neat Reaction Condition. Open Journal of Synthesis Theory and Applications, 6, 23-36. https://doi.org/10.4236/ojsta.2017.63003

Received: July 6, 2017

Accepted: July 28, 2017

Published: July 31, 2017

Copyright $\odot 2017$ by authors and Scientific Research Publishing Inc. This work is licensed under the Creative Commons Attribution-NonCommercial International License (CC BY-NC 4.0). http://creativecommons.org/licenses/by-nc/4.0/ (c) (i) (8) Open Access

\begin{abstract}
A new robust heterogeneous, versatile, an environmentally benign, eco-friendly, recyclable CuFAP catalyst has been developed for the direct synthesis of nitriles and amides from aldehydes at $100^{\circ} \mathrm{C}$ for $6 \mathrm{~h}$ and $4 \mathrm{~h}$, respectively, under neat reaction condition using hydroxylamine hydrochloride in the presence and the absence of tosyl chloride, respectively. Also the recyclability of catalyst as well as influence of solvents, additives on catalysts performance was investigated. The protocol can be considered as an alternative to conventional method for the synthesis of nitriles and amides in good to excellent yields. A highlight of our protocol is the easy separation of catalyst from reaction mixture, hence the catalyst is reused several times without significant loss of its catalytic activity.
\end{abstract}

\section{Keywords}

Heterogeneous, Recyclable, Nitriles, Amide, Aldehyde, Copper Fluorapatite

\section{Introduction}

The nitriles and amides are versatile prolific moieties acting as major building blocks in organic chemistry to synthesise numerous nitrogen-containing heterocyclic compounds which are not only integral part of fine chemicals, agrochemicals, polymer but also medicinally and biologically potent compounds. The nitrile bond containing compounds are used in clinical developments as well as for the preparation of angiotensin 1 receptor ligands, losartan and valsartan [1], 1,2-diarylimidazoles as anti-inflammatory agents [2], thiazole analogues as inhibi- 
tor of superoxides [3] [4] [5]. Owing to the potential applications of nitriles in pharmaceuticals, agricultural chemicals, polymer, dyes [6], various methods for its synthesis such as classic Sandmeyer reaction [7] [8] [9] [10] [11], or nucleophilic substitution of aryl halides with metal cyanide [12] [13] [14] [15], dehydration of aldoximes [16] [17] [18] [19], dehydration of amide [20] [21] [22] [23], amine to nitrile [24] [25] [26], oxidation of alcohols [27] [28], and direct conversion of aldehydes to nitriles using $\mathrm{NH}_{2} \mathrm{OH} \cdot \mathrm{HCl}$ [29], and/or ammonia over $\mathrm{CuCl}_{2} / \mathrm{NaOMe}$ / $\mathrm{O}_{2}$ [30], $\mathrm{Pd}(\mathrm{OAc})_{2}$ [31], Oxone [32], $\mathrm{H}_{2} \mathrm{O}_{2}$ [33], I $\mathrm{I}_{2}$ [34], NBS [35], IBX [36], $\mathrm{NaICl}_{2}$ [37], p-TSA [38], $\mathrm{KF} / \mathrm{Al}_{2} \mathrm{O}_{3}$ [39], catalysts have been well documented. Amides also serve as key precursor for variety chemical transformation/biologically active compounds [40] [41] [42] [43] as well as for the synthesis of peptide, protein, anti-block reagents, colour pigments, detergents and lubricants etc. [44] [45]. Therefore, the various methods for the synthesis of amide using varieties of reagent and catalysts such as enzyme catalyzed hydrolysis of nitriles and or amidation of acids or esters with ammonia [46] [47], Beckmann rearrangement [48] [49], iodine and $\mathrm{H}_{2} \mathrm{O}_{2}$ [50], $\mathrm{Ir}$ [51], $\mathrm{Cu}$ [52], $\mathrm{Ag} / \mathrm{Au}$ [53], Pd [54], Rh [55] [56] [57] [58], $\mathrm{Ru}$ compounds [59] [60], anhydrous oxalic acid [61], Sulfamic acid [62], cyanuric chloride/DMF [63], ethyl chloroformate/boron trifluoride etherate [64], and chlorosulfonic acid [65] have been reported. Moreover, a direct synthesis of nitriles and amides from aldehydes using dry or wet alumina and chitosan supported ionic liquid were reported by Sharghi et al. [66] and Nezhad et al. [67], respectively. Even though significant progress has been achieved, almost all of these approaches developed so far for the synthesis of nitriles and amides suffer from one or other major limitations and drawbacks such as drastic reaction conditions, high temperature, long reaction time, and low yield to desired products. In addition to these limitations, use of non-recoverable, moisture sensitive, toxic, corrosive, expensive reagents and catalysts such as $\mathrm{HCN} /$ metal cyanides, metal/enzyme etc. in excess as well as the prohibitive isolation costs and applicability to a limited range of substrates constitute seriousness for their industrial scale application.

Therefore, addressing limitation and/or issues associated with catalysis is one of the prime important nowadays to develop the green chemical process. Consequently, the development of cost effective, non-toxic, non-corrosive, stable, recyclable, eco-friendly, robust heterogeneous catalysts is still challenging and an active research area. As part of our continuous studies toward development of cost effective, eco-friendly heterogeneous recyclable catalysts for the organic transformation, [68]-[73] herein, we report a simple, novel, solvent free, cost effective protocol using non-toxic, non-corrosive, stable, recyclable, eco-friendly robust heterogeneous CuFAP catalyst for the facile one pot synthesis of a wide range of nitriles and amides from the various aldehydes (Scheme 1), which may be a practical approach for the synthesis of various nitriles and amides.

\section{Results and Discussion}

To optimize the reaction conditions, a series of experiments were performed for 


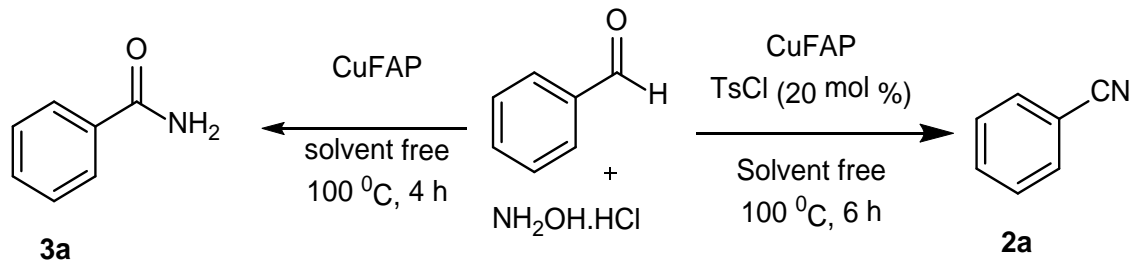

Scheme 1. CuFAP catalysed synthesis of nitriles and amides from aldehydes.

Table 1. Optimization of the reaction conditions. ${ }^{\mathrm{a}}$

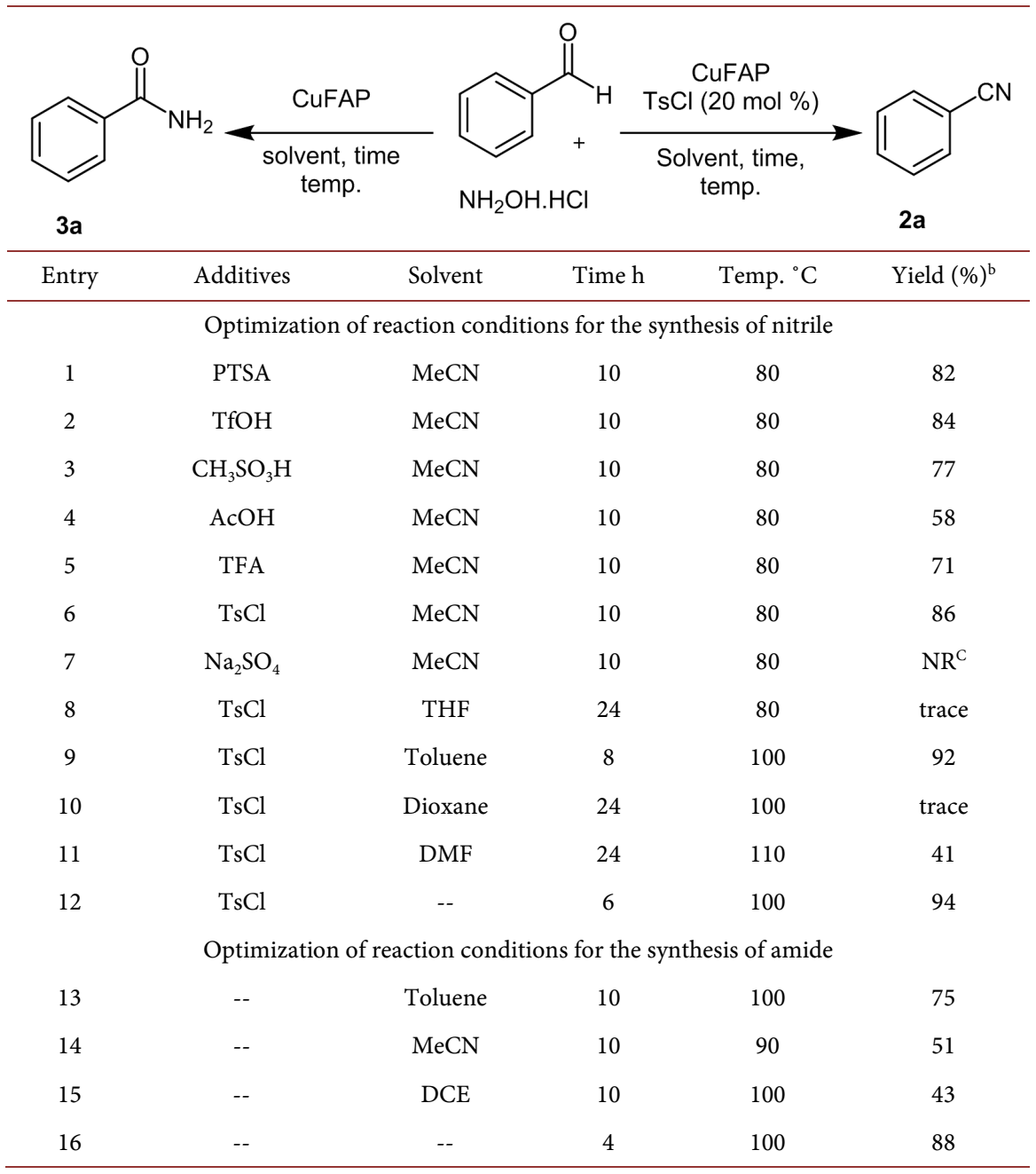

a'Reaction conditions: $1 \mathrm{a}(1 \mathrm{mmol})$, hydroxylamine hydrochloride $(1.2 \mathrm{mmol})$, additives (20 mol\%), solvent $(5 \mathrm{~mL})$, CuFAP $(100 \mathrm{mg}), 80^{\circ} \mathrm{C}-110^{\circ} \mathrm{C}, 4-24 \mathrm{~h}$. ${ }^{\text {b}}$ The yields indicated are the isolated yield by column chromatography ${ }^{\mathrm{C}}$ No reaction, ${ }^{\mathrm{d}} \mathrm{Without}$ catalyst no reaction.

the synthesis of nitriles and amides by reacting benzaldehyde with hydroxylamine hydrochloride salt in the presence and absence of additives, respectively. Initially, we perform the reaction of benzaldehyde $(1 \mathrm{mmole})$ by reacting with hydroxylamine hydrochloride salt $(1.2 \mathrm{mmole})$ in the presence of CuFAP (100 $\mathrm{mg}$ ) catalyst using $20 \mathrm{~mol} \%$ PTSA as an additive in $\mathrm{MeCN}(5 \mathrm{~mL})$ solvent under reflux reaction temperature for $10 \mathrm{~h}$. To our surprise, the expected desired product benzonitrile $2 \mathrm{a}$ was obtained in $82 \%$ yield (entry 1 , Table 1 ). Encour- 
aged by this result, we studied the effect of various additives (entries $1-7$, Table 1). However, tosyl chloride additive gave higher yield to desire product (entry 6 , Table 1) compared to other additives, whereas formation of 2a product was not observed in case sodium sulfate additive (entry 7, Table 1). Moreover, the 10 and $15 \mathrm{~mol} \%$ loading of $\mathrm{TsCl}$ shows inferior yield compared to $20 \mathrm{~mol} \%$. The screening the organic solvent such as THF, PhMe, Dioxane and DMF were carried out by taking $20 \mathrm{~mol} \% \mathrm{TsCl}$ (entries 8 - 11, Table 1). However, the reaction proceeded smoothly in the PhMe solvent to furnish corresponding product in 92\% yield (entry 9, Table 1 ). The THF, dioxane and DMF solvents provided trace and $41 \%$ yield, respectively, in $24 \mathrm{~h}$ (entries 8,10 and 11, Table 1). In addition, the reaction was also performed in solvent free condition at $100^{\circ} \mathrm{C}$, interestingly; desired product was obtained in 94\% yield in $6 \mathrm{~h}$ (entry 12, Table 1).

After achieving the optimization of reaction conditions for the synthesis of nitriles, we switch over our studies to optimize the reaction parameter for the synthesis of amide (3a). The one pot transformation of benzaldehyde was performed in the presence of solvents (PhMe, MeCN, DCE) and in the absence of solvent by reacting hydroxylamine hydrochloride salt without an additives using CuFAP catalyst (entries 13 - 16, Table 1). To our delight, the neat reaction condition provided desired product $3 \mathrm{a}$ in $88 \%$ yield in $4 \mathrm{~h}$. The formation of the desired product either $\mathbf{2 a}$ or $\mathbf{3 a}$ was not observed in the absence of catalyst and/or additive.

Having optimized reaction conditions in hand, we examine the scope and limitation of our protocol for the synthesis of various nitriles and amides. As shown in Table 2, various benzaldehydes were reacted efficiently with hydroxylamine hydrochloride in the presence of additive, and provided the corresponding nitrile product in good to excellent yield (entries $2 \mathrm{a}-2 \mathbf{v}$, Table 2).

Amazingly, the neutral, saturated, unsaturated benzaldehyde as well as benzaldehydes having electron rich and electron poor groups such as such as methyl, methoxy, trimethoxy, chloro, and nitro were efficiently converted into corresponding nitrile product in excellent (entries $2 \mathrm{a}-2 \mathrm{n}, 2 \mathrm{p}, 2 \mathrm{r}$, and $2 \mathrm{~s}$, Table 2) except ortho-nitrobenzaldehyde (entry $2 t$, Table 2 ) gave desire nitrile in good yields. Due to promising results, the scope of protocol was extended to 1-3 benzodioxole-4-carbaldehyde, 3-phenoxybenzaldehyde and heterocyclic aldehydes, miraculously all these aldehydes were smoothly converted into corresponding nitrile in excellent yield (entries $\mathbf{2} \mathbf{o}, \mathbf{2 q}, \mathbf{2} \mathbf{u}$ and $\mathbf{2 v}$, Table 2 ).

Having succeeded the application of a robust heterogeneous recyclable $\mathrm{Cu}$ FAP catalyst for the synthesis of various nitriles, we further elaborated the scope of protocol for the synthesis of amides. As predicted in Table 3, various benzaldehydes were reacted well with hydroxylamine hydrochloride, and delivered the corresponding amide product in good to excellent yield (entries $\mathbf{3 a}-\mathbf{3 o}$, Table 3). The neutral benzaldehyde as well as benzaldehyde having electron rich and electron poor groups such as methyl, methoxy, trimethoxy, chloro, nitro and hydroxy were easily converted into corresponding amides in good to excellent 
Table 2. Substrate scopes of various aromatic nitriles. ${ }^{\mathrm{a}}$<smiles>[R]c1ccc(C=O)cc1</smiles><smiles>CC(O)CC(Cl)ON</smiles>

CUFAP $100{ }^{\circ} \mathrm{C}, 6 \mathrm{~h}$.<smiles>[R]c1ccc(C#N)cc1</smiles>

2a-v<smiles>N#Cc1ccccc1</smiles><smiles>N#Cc1cccc2ccccc12</smiles><smiles>N#Cc1ccc2ccccc2c1</smiles><smiles>N#CCCc1ccccc1</smiles>

2a, $94 \%$

2b, 95\%

2c, $91 \%$

2d, $92 \%$<smiles>N#CC=Cc1ccccc1</smiles><smiles>Cc1ccc(C#N)cc1</smiles>

2e, $95 \%$

2f, $92 \%$<smiles>COc1ccc(C#N)cc1</smiles>

2i, $97 \%$<smiles>COc1cccc(C#N)c1</smiles>

$2 \mathrm{~m}, 93 \%$<smiles>N#Cc1cccc(Oc2ccccc2)c1</smiles>

2q, $96 \%$<smiles>Cn1cc(C#N)c2ccccc21</smiles><smiles>COc1cc(C#N)cc(OC)c1OC</smiles>

2j, $98 \%$<smiles>COc1ccc(C#N)cc1OC</smiles>

2n, $97 \%$<smiles>N#Cc1cccc(Cl)c1</smiles>

2r, 95\%<smiles>N#Cc1cccs1</smiles>

2v, $97 \%$<smiles>Cc1cccc(C#N)c1</smiles>

2h, $93 \%$<smiles>N#Cc1ccc([N+](=O)[O-])cc1</smiles>

2I, $93 \%$<smiles>N#Cc1cccc2c1OCO2</smiles>

2o, $98 \%$<smiles>N#Cc1cccc([N+](=O)[O-])c1</smiles>

2s, $92 \%$<smiles>N#Cc1ccccc1[N+](=O)[O-]</smiles>

2t, $84 \%$

${ }^{a}$ Reactions conditions: $1 \mathrm{a}-1 \mathbf{v}(1 \mathrm{mmol})$, hydroxylamine hydrochloride $(1.2 \mathrm{mmol}), \mathrm{TsCl}(20 \mathrm{Mol} \%) \mathrm{Cu}-$ FAP $(100 \mathrm{mg}), 100^{\circ} \mathrm{C}, 6 \mathrm{~h}$. The yields indicated are the isolated yield after purification. 
Table 3. Substrate scopes of various aromatic primary amides. ${ }^{\mathrm{a}}$<smiles>[R]c1ccccc1C=O</smiles>

1a-o<smiles>[R]c1ccc(C(N)=O)cc1C(=O)O[Na]</smiles>

3a-o<smiles>NC(=O)c1ccccc1</smiles>

3a, $88 \%$<smiles>Cc1ccc(C(N)=O)cc1</smiles>

$3 b, 85 \%$<smiles>CC(C)c1ccc(C(N)=O)cc1</smiles>

3c, $87 \%$<smiles>NC(=O)c1ccc(O)cc1</smiles>

3d, $81 \%$<smiles>COc1ccc(C(N)=O)cc1</smiles>

3e, $90 \%$<smiles>COc1ccc(C(N)=O)cc1OC</smiles>

3f, $93 \%$<smiles>COc1cc(C(N)=O)cc(OC)c1OC</smiles>

$3 g, 84 \%$<smiles>COc1cccc(C(N)=O)c1O</smiles>

$3 \mathbf{j}, 78 \%$<smiles>NC(=O)/C=C/c1ccccc1</smiles>

$3 \mathrm{~m}, 91 \%$<smiles>NC(=O)c1ccc(Cl)cc1</smiles>

$3 h, 82 \%$<smiles>NC(=O)c1ccc2c(c1)OCO2</smiles>

3k, $89 \%$

3I, $95 \%$<smiles>NC(=O)c1ccco1</smiles>

3o, $87 \%$

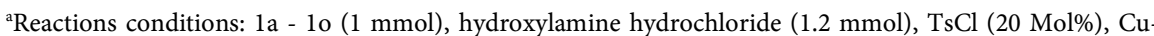
FAP $(100 \mathrm{mg})$ at $100^{\circ} \mathrm{C}$ for $4 \mathrm{~h}$. The yields indicated are the isolated yield after purification. 
yield (entries 3a - 3j, Table 3). Unexpectedly, 1-3 benzodioxole-4-carbaldehyde (entry $3 \mathrm{k}$, Table 3 ), saturated, unsaturated (entry $3 \mathrm{l}$ and $3 \mathrm{~m}$, Table 3 ) and heterocyclic aldehydes (entry $3 \mathrm{n}$ and $\mathbf{3 0}$, Table 3 ) also willing deliver desired corresponding amide in good to excellent yields. The results in Table 2 and Table 3 clearly reveal that developed solvent free protocol over a robust heterogeneous recyclable CuFAP catalyst is facile, efficient, general, and applicable to variety of substrates having different functional groups. Nevertheless, yield achieved is dependent on the functional groups/substituent on the aldehydes.

As per our [68]-[73] and previous [74] [75] research work reported in the literature over copper fluoroapatite catalyst, a possible reaction pathway for one pot synthesis of nitriles and amides from benzaldehyde is outlined in Scheme 2. Initially benzaldehyde and hydroxylamine hydrochloride reacts to form aldoxime (I) which on coordination with CuFAP catalyst provide intermediate complex (II). The complex II on hydrolysis with water generate the complex III which is instantaneously undergo rearrangement to eliminate of CuFAP catalyst as well as amide, whereas the complex II reacts with tosyl chloride additive to release the CuFAP and nitrile.

The recyclability and reusability of the copper fluorapatite catalyst for one-pot synthesis of nitriles and amides from benzaldehyde was investigated under optimized reaction conditions, and results are summarized in Table 4. The CuFAP catalyst was recovered quantitatively from the reaction mixture by simple filtration and reused several times without loss of catalytic activity. The isolated yield obtained for desired products ( $2 a$ and $3 a$ ) even after forth recycle is comparable with fresh CuFAP catalyst.

\section{Conclusion}

In conclusion, the CuFAP is an efficient, versatile, ecofriendly, inexpensive, nontoxic, reusable heterogeneous and green catalyst has been developed for a

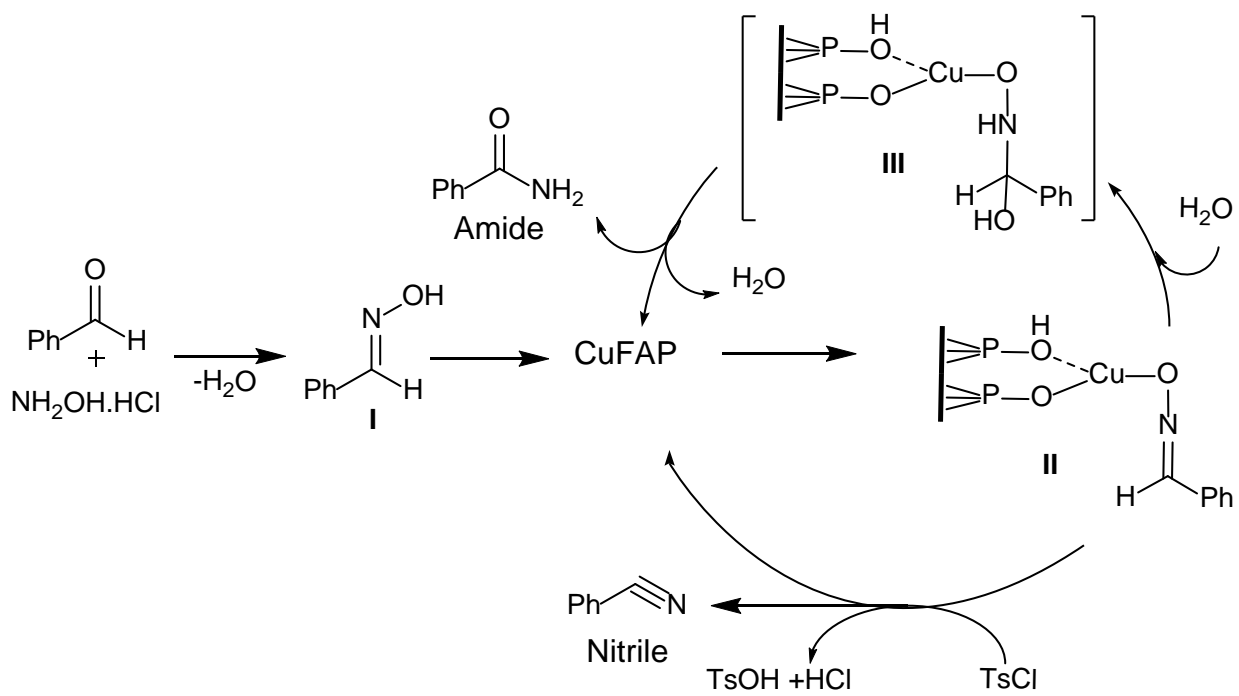

Scheme 2. Plausible mechanism for the nitrile and amide synthesis over CuFAP catalyst. 
Table 4. Recyclability of catalyst.

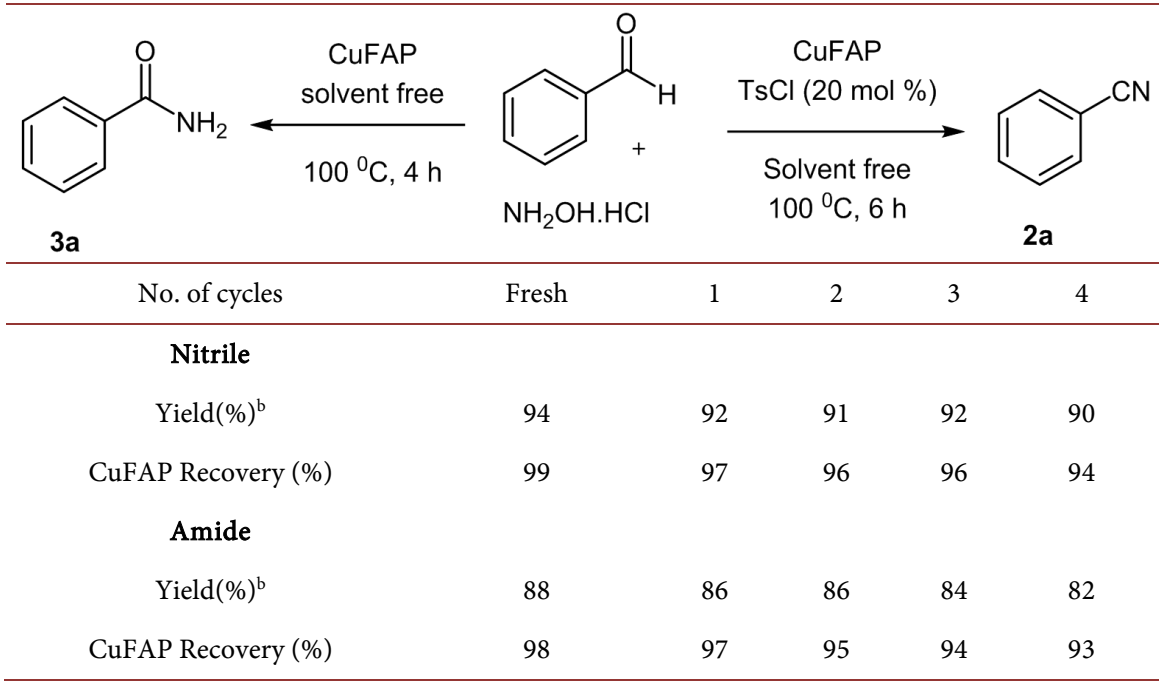

${ }^{a}$ Reaction conditions: benzaldehyde $(1 \mathrm{mmol})$, hydroxyl amine hydrochloride $(1.2 \mathrm{mmol})$, except TsCl $(20$ $\mathrm{mol} \%$ ) (used in case of nitrile) at $100^{\circ} \mathrm{C}$. ${ }^{\mathrm{b}}$ The yields indicated are the isolated yields by column chromatography.

one-pot synthesis of various nitriles and amides via aldoximes formation from various aldehydes at $100^{\circ} \mathrm{C}$ for $6 \mathrm{~h}$ and $4 \mathrm{~h}$, respectively, under neat reaction condition using hydroxylamine hydrochloride in the presence and the absence of tosyl chloride, respectively. The following features make this methodology attractive: a) its simplicity, clean, efficient, rapid, mild, and neat reactions conditions, b) the protocol is very general and it works well with variety of aldehydes affording good to excellent yields, c) the CuFAP catalyst is recovered and reused without further purifications and gave $90 \%$ - $94 \%$ yield to the nitriles and $82 \%$ $88 \%$ yield to the amides without loss of catalytic activity. The further studies are expected for an industrial scale application of CuFAP catalyst in our research group.

\section{Experimental Section}

All chemicals and reagents were procured from suppliers and used without further purification. The products were characterized using ${ }^{1} \mathrm{H}$ NMR, ${ }^{13} \mathrm{C}$ NMR spectra. NMR spectrums of product were obtained using Bruker AC-200 MHz spectrometer with TMS as the internal standard.

\subsection{Typical Experimental Procedure for the Synthesis of Nitriles}

In a $10 \mathrm{~mL}$ round bottom flask equipped with aldehydes $(1 \mathrm{mmol})$, hydroxylamine hydrochloride (1.2 mmol), TsCl (20 mol\%) and CuFAP catalyst (100 mg) were taken. Then the resulting reaction mixture was refluxed at $100^{\circ} \mathrm{C}$ for $6 \mathrm{~h}$ (Table 2) and the progress of the reaction was monitored by TLC. Upon completion of the reaction, the reaction mixture was diluted with $15 \mathrm{~mL}$ Ethyl acetate followed by filtration to recover the catalyst. The filtrate was washed with 10 $\mathrm{mL}$ solution of $10 \% \mathrm{NaHCO}_{3}$ and organic layer was dried over anhydrous 
$\mathrm{Na}_{2} \mathrm{SO}_{4}$ and concentrated by rotary evaporation to get the crude nitrile compounds, all compounds were isolated without column chromatography.

\subsection{Typical Experimental Procedure for the Synthesis of Amides}

In a $10 \mathrm{~mL}$ round bottom flask equipped with aldehydes $(1 \mathrm{mmol})$, hydroxylamine hydrochloride $(1.2 \mathrm{mmol})$, and CuFAP catalyst $(100 \mathrm{mg})$ were taken. Then the reaction mixture was refluxed at $100^{\circ} \mathrm{C}$ for $4 \mathrm{~h}$ (Table 3 ) and the progress of the reaction was monitored by TLC. Upon completion of the reaction, the reaction mixture was diluted with $15 \mathrm{~mL}$ Ethyl acetate followed by filtration to recover the catalyst. The filtrate was washed with $10 \mathrm{~mL}$ solution of $10 \% \mathrm{NaHCO}_{3}$ and organic layer was dried over anhydrous $\mathrm{Na}_{2} \mathrm{SO}_{4}$ and concentrated by rotary evaporation to get the crude amide, all compounds $3 \mathrm{a}$ - 3o were isolated by column chromatography (ethyl acetate: Pet ether 3:7).

\section{Acknowledgements}

TMYS thanks to UGC New Delhi for a SRF. The authors also thank to Dr. S. S. Tambe, Chair, CE-PD for their encouragement and support.

\section{References}

[1] Khanna, I.K., Weier, R.M., Yu, Y., Xu, X.D., Koszyk, F.J., Callins, P.W., Kobaldt, C.M..Veenhuizen, A.W., Perkins, W.E., Casler, J.J., Masferrer, J.L., Zhung, Y.Y., Gregory, S.A., Seibert, K., and Isakson, P.C. (1997) 1,2-Diarylimidazoles as Potent, Cyclooxygenase-2 Selective, and Orally Active Antiinflammatory Agents. Journal of Medicinal Chemistry, 40, 1626-1647. https://doi.org/10.1021/jm9700225

[2] Fabiani, M.E. (1999) Angiotensin Receptor Subtypes: Novel Targets for Cardiovascular Therapy. Drug News Perspect, 12, 207-215.

[3] Chihiro, M., Nagamoto, H., Takemura, I., Kitano, K., Komatsu, H., Sekiguchi, K., Tabusa, F., Mori, T., Tominnaga, M. and Yabuuchi, Y. (1995) Novel Thiazole Derivatives as Inhibitors of Superoxide Production by Human Neutrophils: Synthesis and Structure-Activity Relationships. Journal of Medicinal Chemistry, 38, 353-358. https://doi.org/10.1021/jm00002a017

[4] Miller, J.S. and Manson, J.L. (2001) Designer Magnets Containing Cyanides and Nitriles. Accounts of Chemical Research, 34, 563-570. https://www.ncbi.nlm.nih.gov/pubmed/11456474 https://doi.org/10.1021/ar0000354

[5] Fatiadi, A.J. (1983) Preparation and Synthetic Applications of Cyano Compounds. In: Patai, S. and Rappaport Z., Eds., Wiley, New York. https://doi.org/10.1002/9780470771709.ch9

[6] Magnus, P., Scott, D.A. and Fielding, M.R. (2001) Direct Conversion of $\alpha, \beta$-Unsaturated Nitriles into Cyanohydrins Using $\mathrm{Mn}(\mathrm{dpm})_{3}$ Catalyst, Dioxygen and Phenylsilane. Tetrahedron Letters, 42, 4127-4129. https://doi.org/10.1016/S0040-4039(01)00693-1

[7] Xu, W.B., Xu, Q.H., Zhang, Z.F. and Li, J.Z. (2014) Copper(I)-Oxide-Mediated Cyanation of Arenediazonium Tetrafluoroborates with Trimethylsilyl Cyanide: A Method for Synthesizing Aromatic Nitriles. Asian Journal of Organic Chemistry, 3, 1062-1065. https://doi.org/10.1002/ajoc.201402084 
[8] Sandmeyer, T. (1884) Ueber die Ersetzung der Ueber die Ersetzung der Amidgruppe durch Chlor in den aromatischen Substanzen. Berichte der Deutschen Chemischen Gesellschaft, 17, 1633-1635. https://doi.org/10.1002/cber.18840170219

[9] Kochi, J.K. (1957) The Mechanism of the Sandmeyer and Meerwein Reactions. Journal of the American Chemical Society, 79, 2942-2948. https://doi.org/10.1021/ja01568a066

[10] Lindley, J. (1984) Copper Assisted Nucleophilic Substitution of Aryl Halogen. Tetrahedron, 40, 1433-1456. https://doi.org/10.1016/S0040-4020(01)91791-0

[11] Hodgson, H.H. (1947) The Saydimeyer Reaction. Chemical Reviews, 40, 251-277. https://doi.org/10.1021/cr60126a003

[12] Ushkov, A.V. and Grushin, V.V. (2011) Rational Catalysis Design on the Basis of Mechanistic Understanding: Highly Efficient Pd-Catalyzed Cyanation of Aryl Bromides with $\mathrm{NaCN}$ in Recyclable Solvents. Journal of the American Chemical Society, 133, 10999-11005. https://doi.org/10.1021/ja2042035

[13] Yeung, P.Y, So, C.M., Lau, C.P. and Kwong, F.Y. (2011) A Mild and Efficient Palladium-Catalyzed Cyanation of Aryl Chlorides with $\mathrm{K}_{4}\left[\mathrm{Fe}(\mathrm{CN})_{6}\right]$. Organic Letters, 13, 648-651. https://doi.org/10.1021/ol1028892

[14] Zanon, J., Klapars, A. and Buchwald, S.L. (2003) Copper-Catalyzed Domino Halide Exchange-Cyanation of Aryl Bromides. Journal of the American Chemical Society, 125, 2890-2891. https://doi.org/10.1021/ja0299708

[15] Grossman, O. and Gelman, D. (2006) Novel Trans-Spanned Palladium Complexes as Efficient Catalysts in Mild and Amine-Free Cyanation of Aryl Bromides under Air. Organic Letters, 8, 1189-1191. https://doi.org/10.1021/ol0601038

[16] Choi, E., Lee, C., Na, Y. and Chang, S. (2002) $\left[\mathrm{RuCl}_{2}(p \text {-cymene) }]_{2}\right.$ on Carbon: An Efficient, Slective, Reusable, and Environmentally Versatile Heterogeneous Catalyst. Organic Letters, 4, 2369-2371. https://doi.org/10.1021/ol0260977

[17] Chandrasekhar, S. and Gopalaiah, K. (2003) Beckmann Reaction of Oximes Catalysed by Chloral: Mild and Neutral Procedures. Tetrahedron Letters, 44, 755-756. https://doi.org/10.1016/S0040-4039(02)02644-8

[18] Yamaguchi, K., Fujiwara, H., Ogasawara, Y., Kotani, M. and Mizuno, N.A. (2007) A Tungsten-Tin Mixed Hydroxide as an Efficient Heterogeneous Catalyst for Dehydration of Aldoximes to Nitriles. Angewandte Chemie International Edition, 46, 3922-3925. https://doi.org/10.1002/anie.200605004

[19] Ishihara, K., Furuya, Y. and Yamamoto, H. (2002) Rhenium(vii) Oxo Complexes as Extremely Active Catalysts in the Dehydration of Primary Amides and Aldoximes to Nitriles. Angewandte Chemie International Edition, 41, 2983-2985. https://doi.org/10.1002/1521-3773(20020816)41:16<2983::AID-ANIE2983>3.0.CO;2 $\underline{-\mathrm{X}}$

[20] Maffioli, S.I., Marzorati, E. and Marazzi, A. (2005) Mild and Reversible Dehydration of Primary Amides with $\mathrm{PdCl}_{2}$ in Aqueous Acetonitrile. Organic Letters, 7, 5237-5239. https://doi.org/10.1021/ol0521001

[21] Enthaler, S. (2011) Straightforward Iron-Catalyzed Synthesis of Nitriles by Dehydration of Primary Amides. European Journal of Organic Chemistry, 4760-4763. https://doi.org/10.1002/ejoc.201100754

[22] Enthaler, S. and Inoue, S. (2012) An Efficient Zinc-Catalyzed Dehydration of Primary Amides to Nitriles. Chemistry-An Asian Journal, 7, 169-175. https://doi.org/10.1002/asia.201100493

[23] Boruah, M. and Konwar, D. (2002) $\mathrm{AlCl}_{3} 6 \mathrm{H}_{2} \mathrm{O} / \mathrm{KI} / \mathrm{H}_{2} \mathrm{O} / \mathrm{CH}_{3} \mathrm{CN}$ : A New Alternate 
System for Dehydration of Oximes and Amides in Hydrated Media. The Journal of Organic Chemistry, 67, 7138-7139. https://doi.org/10.1021/jo020005+

[24] Yamaguchi, K. and Mizuno, N. (2003) Efficient Heterogeneous Aerobic Oxidation of Amines by a Supported Ruthenium Catalyst. Angewandte Chemie International Edition, 42, 1480-1483. https://doi.org/10.1002/anie.200250779

[25] Nicolaou, K.C. and Mathison, C.J.N. (2005) Synthesis of Imides, N-Acyl Vinylogous Carbamates and Ureas, and Nitriles by Oxidation of Amides and Amines with Dess-Martin Periodinane. Angewandte Chemie International Edition, 44, 5992-5997. https://doi.org/10.1002/anie.200501853

[26] Chen, F.-E., Kuang, Y.-Y., Dai, H.-F., Lu, L. and Huo, M. (2003) A Selective and Mild Oxidation of Primary Amines to Nitriles with Trichloroisocyanuric Acid. Synthesis, 2629-2631. https://doi.org/10.1055/s-2003-42431

[27] Vaghei, R. and Veisi, G.H. (2009) Poly ( $N, N^{\mathcal{P}}$-dichloro- $N$-ethylbenzene-1,3 disulfonamide) and $N, N, N, N$ '-Tetrachlorobenzene 1,3-disulfonamide as Novel Reagents for the Synthesis of $N$-Chloroamines, Nitriles and Aldehydes. Synthesis, 945-950. https://doi.org/10.1055/s-0028-1087967

[28] Chen, F.E.Y., Li, Y., Xu, M. and Jia, H.Q. (2002) Tetrabutylammonium Peroxydisulfate in Organic Synthesis; XIII.1 A Simple and Highly Efficient One-Pot Synthesis of Nitriles by Nickel-Catalyzed Oxidation of Primary Alcohols with Tetrabutylammonium Peroxydisulfate. Synthesis, 1804-1806.

https://www.thieme-connect.com/products/ejournals/abstract/10.1055/s-2002-3390 6

[29] Brackman, W. and Smith, P.J. (1963) A New Synthesis of Nitriles. Recueil des Travaux Chimiques des PaysBas, 82, 757-762. https://doi.org/10.1002/recl.19630820803

[30] Parameswaran, K.N. and Friedman, O.M. (1965) Synthesis of Nitriles from Aldehydes. Chemistry \& Industry, 988-989. https://www.ncbi.nlm.nih.gov/pubmed/5842016

[31] Bose, D.S. and Narsaiah, A.V. (1998) Efficient One Pot Synthesis of Nitriles from Aldehydes in Solid State using Peroxymonosulfate on Alumina. Tetrahedron Letters, 39, 6533-6534. https://doi.org/10.1016/S0040-4039(98)01358-6

[32] Erman, M.B., Snow, J.W. and Williams, M.J. (2000) A New Efficient Method for the Conversion of Aldehydes into Nitriles using Ammonia and Hydrogen Peroxide. Tetrahedron Letters, 41, 6749-6752. https://doi.org/10.1016/S0040-4039(00)01168-0

[33] Talukdar, S., Hsu, J.-L., Chou, T.-C. and Fang, J.-M. (2001) Direct Transformation of Aldehydes to Nitriles using Iodine in Ammonia Water. Tetrahedron Letters, 42, 1103-1105. https://doi.org/10.1016/S0040-4039(00)02195-X

[34] Bandgar, B.P. and Makone, S.S. (2006) Organic Reactions in Water: Transformation of Aldehydes to Nitriles using NBS under Mild Conditions. Synthetic Communications, 36, 1347-1352. https://doi.org/10.1080/00397910500522009

[35] Arote, N.D., Bhalerao, D.S. and Akamanchi, K.G. (2007) Direct Oxidative Conversion of Aldehydes to Nitriles using IBX in Aqueous Ammonia. Tetrahedron Letters, 48, 3651-3653. https://doi.org/10.1016/j.tetlet.2007.03.137

[36] Telvekar, V.N., Patel, K.N., Kundiakar, H.S. and Chaudhari, H.K. (2008) A Novel System for the Synthesis of Nitriles from Aldehydes using Aqueous Ammonia and Sodium Dichloroiodate. Tetrahedron Letters, 49, 2213-2215.

https://doi.org/10.1016/j.tetlet.2008.02.046

[37] Reddy, M.B.M. and Pasha, M.A. (2010) Efficient and High-Yielding Protocol for the 
Synthesis of Nitriles from Aldehydes. Synthetic Communications, 40, 3384-3389. https://doi.org/10.1080/00397910903419894

[38] Gozum, V.P. and Mebane, R.C. (2013) Solvent-Free and Atom Efficient Conversion of Aldehydes into Nitriles. Green Chemistry Letters and Reviews, 6, 149. https://doi.org/10.1080/17518253.2012.728633

[39] Barahman, M. and Salman, S. (2005) An Efficient and Convenient KF/Al2O3 Mediated Synthesis of Nitriles from Aldehydes. Tetrahedron Letters, 46, 6923-6925. https://doi.org/10.1016/j.tetlet.2005.08.007

[40] Greenberg, A., Breneman, C.M. and Liebman, J.F. (2000) The Amide Linkage: Structural Significance in Chemistry Biochemistry and Material Science. Wiley, New York.

[41] Kroschwitz, J.I. (1991) C. E. Mabermann in Encyclopedia of Chemical Technology. Vol. 1, Wiley, New York, 251.

[42] Kroschwitz, J.I. (1991) D. Lipp in Encyclopedia of Chemical Technology. Vol. 1, Wiley, New York, 266.

[43] Carey, J.S., Laffan, D., Thomson, C. and Williams, M.T. (2006) Analysis of the Reactions Used for the Preparation of Drug Candidate Molecules. Organic \& Biomolecular Chemistry, 4, 2337-2347. https://doi.org/10.1039/b602413k

[44] Kroschwitz, J.I. (1991) Mabermann, C. E. in Encyclopedia of Chemical Technology. Vol. 1, Wiley, New York, 251.

[45] Kroschwitz, J.I. (1991) R. Opsahl in Encyclopedia of Chemical Technology. Vol. 2, Wiley, New York, 346.

[46] Wang, M.-X. (2005) Enantioselective Biotransformations of Nitriles in Organic Synthesis. Topics in Catalysis, 35, 117-135. https://doi.org/10.1007/s11244-005-3817-1

[47] Kumar, D. and Bhalla, T.C. (2005) Microbial Proteases in Peptide Synthesis: Approaches and Applications. Applied Microbiology and Biotechnology, 68, 726-736. https://doi.org/10.1007/s00253-005-0094-7

[48] Gawley, R.E. (1988) The Beckmann Reactions: Rearrangements, Elimination-Additions, Fragmentations, and Rearrangement-Cyclisations. Organic Reactions, 35, 1-247. https://doi.org/10.1002/0471264180.or035.01

[49] Izumi, Y., Sato, S. and Urabe, K. (1983) Vapor-Phase Beckmann Rearrangement of Cyclohexanone Oxime over Boria-Hydroxyapatite Catalyst. Chemistry Letters, 1649-1652. https://doi.org/10.1246/cl.1983.1649

[50] Shie, J. and Fang, J (2003) Direct Conversion of Aldehydes to Amides, Tetrazoles, and Triazines in Aqueous Media by One-Pot Tandem Reactions. The Journal of Organic Chemistry, 68, 1158-1160. https://doi.org/10.1021/jo026407z

[51] Owston, N.A., Parker, A.J. and Williams, J.M. (2007) Iridium-Catalyzed Conversion of Alcohols into Amides via Oximes. Organic Letters, 9, 73-75. https://doi.org/10.1021/ol062549u

[52] Ghosh, S.C., Ngiam, J.S.Y., Seayad, A.M., Tuan, D.T., Chai, C.L.L. and Chen, A. (2012) Coppee-Catalyzed Oxidative Amidation of Aldehydes with Amine Salt: Synthesis of Primary, Secondary, Tertiary Amides. The Journal of Organic Chemistry, 77, 8007-8015. https://doi.org/10.1021/jo301252c

[53] Ramon, R.S., Bosson, J., González, S.D., Marion, N. and Nolan, S.P. (2010) $\mathrm{Au} / \mathrm{Ag}$-Cocatalyzed Aldoximes to Amides Rearrangement under Solvent- and Acid-Free Conditions. The Journal of Organic Chemistry, 75, 1197-1202. https://doi.org/10.1021/jo902461a 
[54] Ali, M.A. and Punniyamurthy, T. (2010) Palladium-Catalyzed One-Pot Conversion of Aldehydes to Amides. Advanced Synthesis \& Catalysis, 352, 288-292. https://doi.org/10.1002/adsc.200900799

[55] Park, S., Choi, Y., Han, H., Yang, S.H. and Chang, S. (2003) Rh-Catalyzed One-Pot and Practical Transformation of Aldoximes to Amides. Chemical Communications, 1936-1937. https://doi.org/10.1039/b305268k

[56] Fujiwara, H., Ogasawara, Y., Yamaguchi, K. and Mizuno, N.A. (2007) A One-Pot Synthesis of Primary Amides from Aldoximes or Aldehydes in Water in the Presence of a Supported Rhodium Catalyst. Angewandte Chemie International Edition, 46, 5202-5205. https://doi.org/10.1002/anie.200701273

[57] Fujiwara, H., Ogasawara, Y., Kotani, M., Yamaguchi, K. and Mizuno, N. (2008) A Supported Rhodium Hydroxide Catalyst: Preparation, Characterization, and Scope of the Synthesis of Primary Amides from Aldoximes or Aldehydes. Chemistry-An Asian Journal, 3, 1715-1721. https://doi.org/10.1002/asia.200800067

[58] Kim, M., Lee, J., Lee, H.-Y. and Chang, S. (2009) Significant Self-Acceleration Effects of Nitrile Additives in the Rhodium-Catalyzed Conversion of Aldoximes to Amides: A New Mechanistic Aspect. Advanced Synthesis \& Catalysis, 351, 1807-1812. https://doi.org/10.1002/adsc.200900251

[59] Gnanamgari, D. and Crabtree, R.H. (2009) Terpyridine Ruthenium-Catalyzed One-Pot Conversion of Aldehydes into Amides. Organometallics, 28, 922-924. https://doi.org/10.1021/om8010678

[60] Hull, J.F., Hilton, S.T. and Crabtree, R.H. (2010) A Simple Ru Catalyst for the Conversion of Aldehydes or Oximes to Primary Amides. Inorganica Chimica Acta, 363, 1243-1245. https://doi.org/10.1016/j.ica.2009.08.022

[61] Chandrasekhar, S. and Gopalaiah, K. (2002) Beckmann Rearrangement of Ketoximes on Solid Metaboric Acid: A Simple and Effective Procedure. Tetrahedron Letters, 43, 2455-2457. https://doi.org/10.1016/S0040-4039(02)00282-4

[62] Wang, B., Gu, Y., Luo, C., Yang, T., Yang, L. and Suo, J. (2004) Sulfamic Acid as a Cost-Effective and Recyclable Catalyst for Liquid Beckmann Rearrangement, a Green Process to Produce Amides from Ketoximes without Waste. Tetrahedron Letters, 45, 3369-3372. https://doi.org/10.1016/j.tetlet.2004.03.017

[63] De Luca, L., Giacomelli, G. and Porcheddu, A. (2002) Beckmann Rearrangement of Oximes under Very Mild Conditions. The Journal of Organic Chemistry, 67, 6272-6274. https://doi.org/10.1021/jo025960d

[64] Antikumar, S. and Chandrasekhar, S. (2000) Improved Procedures for the Beckmann Rearrangement: The Reaction of Ketoxime Carbonates with Boron Trifluoride Etherate. Tetrahedron Letters, 41, 5427-5429. https://doi.org/10.1016/S0040-4039(00)00875-3

[65] Li, D., Shi, F., Guo, S. and Deng, Y. (2005) Highly Efficient Beckmann Rearrangement and Dehydration of Oximes. Tetrahedron Letters, 46, 671-674. https://doi.org/10.1016/j.tetlet.2004.11.116

[66] Sharghi, H. and Sarvari, M.H. (2002) A Direct Synthesis of Nitriles and Amides from Aldehydes using Dry or Wet Alumina in Solvent Free Conditions. Tetrahedron, 58, 10323-10328. https://doi.org/10.1016/S0040-4020(02)01417-5

[67] Khalafi-Nezhad, A. and Mohammadi, S. (2014) Chitosan Supported Ionic Liquid: A Recyclable Wet and Dry Catalyst for the Direct Conversion of Aldehydes into Nitriles and Amides under Mild Conditions. RSC Advances, 4, 13782-13787. http://pubs.rsc.org/en/content/articlelanding/2014/ra/c3ra43440k 
[68] Mulla, S.A.R., Chavan, S.S., Pathan, M.Y., Inamdar, S.M. and Shaikh, T.M.Y. (2015) Ligand-, Base-, Co-Catalyst-Free Copper Fluorapatite (CuFAP) as a Versatile, Ecofriendly, Heterogeneous and Reusable Catalyst for an Efficient Homocoupling of Arylboronic Acid at Ambient Reaction Conditions. RSC Advances, 5, 24675-24680. http://pubs.rsc.org/en/content/articlelanding/2015/ra/c4ra16760k

[69] Mulla, S.A.R., Chavan, S.S., Pathan, M.Y., Inamdar, S.M. and Shaikh, T.M.Y. (2014) An Efficient Synthesis of O-Aryloxime Ethers by Copper Fluorapatite Catalyzed Cross-Coupling of Aryloximes with Arylboronic Acids. Tetrahedron Letters, 55, 5327-5332. https://doi.org/10.1016/j.tetlet.2014.07.056

[70] Mulla, S.A.R., Inamdar, S.M., Pathan, M.Y. and Chavan, S.S. (2012) Ligand Free, Highly Efficient Synthesis of Diaryl Ether over Copper Fluorapatite as Heterogeneous Reusable Catalyst. Tetrahedron Letters, 53, 1826-1829. https://doi.org/10.1016/j.tetlet.2012.01.124

[71] Mulla, S.A.R., Inamdar, S.M., Pathan, M.Y. and Chavan, S.S. (2012) Base Promoted Highly Efficient Copper Fluorapatite Catalyzed Coupling of Phenols with Arylboronic Acids under Mild and Ligand-Free Conditions. RSC Advances, 2, 12818-12823. http://pubs.rsc.org/en/content/articlelanding/2012/ra/c2ra21850j

[72] Mulla, S.A.R., Pathan, M.Y. and Chavan, S.S. (2013) A Novel and Efficient Synthesis of Azaarene-Substituted 3-Hydroxy-2-Oxindoles via $\mathrm{sp}^{3} \mathrm{C}-\mathrm{H}$ Functionalization of 2-Methyl Azaarenes and (2-azaaryl)methanes over a Heterogeneous, Reusable Silica-Supported Dodecatungstophosphoric Acid Catalyst. RSC Advances, 3, 20281-20286. http://pubs.rsc.org/en/content/articlelanding/2013/ra/c3ra43515f

[73] Mulla, S.A.R., Pathan, M.Y., Chavan, S.S., Gample, S. and Sarkar, P.D. (2014) Highly Efficient One-Pot Multi-Component Synthesis of A-aminophosphonates and Bis-aaminophosphonates Catalyzed by Heterogeneous Reusable Silica Supported Dodecatungstophosphoric Acid $\left(\mathrm{DTP} / \mathrm{SiO}_{2}\right)$ at Ambient Temperature and Their Antitubercular Evaluation against Mycobactrium Tuberculosis. RSC Advances, 4, 7666-7672. http://pubs.rsc.org/en/content/articlehtml/2013/ra/c3ra45853a

[74] Choudary, B.M., Sridhar, C., Kantam, M.L., Venkanna, G.T. and Sreedhar, B. (2005) Design and Evolution of Copper Apatite Catalysts for N-Arylation of Heterocycles with Chloro- and Fluoroarenes. Journal of the American Chemical Society, 127, 9948-9949. https://doi.org/10.1021/ja0436594

[75] Sharghi, H. and Sarvari, M.H. (2003) Graphite as an Efficient Catalyst for One-Step Conversion of Aldehydes into Nitriles in Dry Media. Synthesis, 2, 243-246.

https://doi.org/10.1055/s-2003-36830 